Article

\title{
Social Impact, Innovations, and Market Activity of Social Enterprises: Comparison of European Countries
}

\author{
Barbara Bradač Hojnik and Katja Crnogaj * \\ Faculty of Economics and Business, University of Maribor, 2000 Maribor, Slovenia; barbara.bradac@um.si \\ * Correspondence: katja.crnogaj@um.si; Tel.: +386-2-22-90-263
}

Received: 7 February 2020; Accepted: 28 February 2020; Published: 3 March 2020

check for updates

\begin{abstract}
The purpose of this article is to provide an insight into the specifics of social entrepreneurship in different business environments. The article, therefore, examines selected characteristics of social enterprises, namely social value, innovations, and market activities. In addition, differences in the start-up and operational phases of social enterprises were measured. Social enterprises must operate in a specific business context, which essentially hinders or promotes social entrepreneurship. As culture differs between north-western and south-eastern Europe, it is important to examine the differences in social entrepreneurship between these two groups of countries. To analyze the proposed characteristics, we used the latest data from the Global Entrepreneurship Monitor special report on social entrepreneurship. The results indicate that there exist differences in social impact measurement between observed groups of countries. Additionally, we confirmed differences between the observed groups of countries in terms of innovations and market activity of social enterprises in the operational phase. Our results also suggest that social entrepreneurship is more developed in north-western European countries than in south-eastern ones, with some elements in the north-western countries being more noticeable in the operational phase compared to the start-up phase.
\end{abstract}

Keywords: social entrepreneurship; social value creation; innovations; market activity; Global Entrepreneurship Monitor (GEM)

\section{Introduction}

Social entrepreneurship has emerged as a global phenomenon and has received attention in the literature over the last three decades (e.g., [1-10]) as an important tool for addressing social challenges and responding to those challenges when the market and the public sector fail to do so.

Although interest in social entrepreneurship has increased significantly, there is still a lack of clear definition (e.g., [11-13]) due to the diverse approaches to the issues. According to Bonfanti et al. [14], social entrepreneurship is generally understood as the process by which entrepreneurs pursue a social mission (e.g., [3,15,16]), which can be expressed in terms of social change [17], social transformation [18], social value creation (e.g., [1,19-22]), or social impact, and which aims to solve social problems and needs (e.g., [4,23]) or to create social rather than personal and shareholder wealth [22]. Social entrepreneurship is essentially used to describe activities that, based on innovative approaches, combine entrepreneurial goals with social objectives in order to achieve a social mission and value.

The core of social entrepreneurship is its non-profit character, which aims to create sustainable value and social change in social issues in society (e.g., [22,24,25]). Several authors (e.g., [12,13,26]) understand social entrepreneurship as a concept with several dimensions or sub-concepts, including social entrepreneurs, social enterprise, social value creation, market orientation, and innovation.

Since the process of social entrepreneurship combines "resources in new ways" [22], the development of new solutions is fundamental to creating opportunities for the creation of social value. The social value 
consists mainly in meeting the basic and long-standing needs of those members of society who are in need [27] rather than focusing on the personal or profit of shareholders. Social entrepreneurship has been generally characterized as the creation of innovative social ventures $[28,29]$ and the use of market-based activities to meet social needs and generate income through innovation [23]. As observed by Kusa [30], the theoretical framework for social entrepreneurship can be analyzed using the theory of entrepreneurship as a universal phenomenon existing in different kinds of activities. These entrepreneurial activities can be observed also in non-profit organizations and "profit for purpose" organizations [31], which create social value directly or indirectly and are analyzed in the frame of social entrepreneurship concept, which serves as the theoretical foundation for the analysis.

A consensus is emerging that it is important to understand the phenomenon of social entrepreneurship, as it has an impact on social and economic development [20,32], as it creates both social value for society and economic benefits. The analysis of the status of social entrepreneurship is still sparse [20], especially in international comparison. In addition, most of the analysis is based on conceptual approaches to social entrepreneurship (e.g., [11,13,33-35]) or on case studies. Moreover, the analysis of social entrepreneurship is largely concerned with the definition of the concept and does not provide an in-depth analysis.

However, some recent research (e.g., [36-38]) suggests that social entrepreneurship is influenced by both individual and contextual characteristics as determinants that influence the characteristics of social entrepreneurship activity, in particular, the way in which social enterprises are developed in a particular business context or national context. Although the identification and exploitation of opportunities in the literature on for-profit entrepreneurship have been examined from various perspectives, several authors believe that there is still little empirical research on how social entrepreneurship differs internationally (e.g., [39-41]).

Perrini, Vurro, and Costanzo [40] as well as Chowdhury and Santos [42] pay attention to further research on scaling-up of social enterprises. Perrini, Vurro, and Costanzo [40] explain factors that influence the development of entrepreneurial initiatives. Other researchers note the importance of social value creation and argue about the lack of research in the social entrepreneurship process and the development of social initiatives (e.g., [4,43-45]). Austin, Stevenson, and Wei-Skillern [19] confirm that evaluating social entrepreneurship as an activity, its inputs, and the impact it produces is a complex, complicated, and unmetered process. In the absence of a common attitude towards the development of social entrepreneurship initiatives, there is a need for further research [38]. In this article, we fill this gap by comparing social entrepreneurship in a competitive environment to explain the differences between social enterprises, their innovation, social value creation, and market activities in different cultural and business environments or contexts.

By analyzing characteristics of social entrepreneurship from the perspective of international comparison, the article attempts to provide a deeper insight into the differences of phenomena of social entrepreneurship in different cultural contexts by dividing them into two groups, namely north-western (NwECs) and south-eastern European countries (SeECs). This article aims to determine whether different business and cultural contexts influence the characteristics of social entrepreneurship. Since culture by its very nature sets the boundaries for entrepreneurial activity [46-48], it can influence how entrepreneurs use their resources to contribute to social well-being. In this view, the allocation of resources to social value creation cannot be considered in isolation from the broader context of the business environment in which social entrepreneurship activity takes place. Entrepreneurs are embedded in a number of characteristics of the business environment; they cannot act independently of the situation in which they find themselves. The article, therefore, focuses on the question of whether social entrepreneurs in certain business environments measure social value, innovations, and market activity as essential characteristics of social enterprises.

The article builds on the analysis and synthesis of the scientific literature, which allows us to describe the phenomenon of social entrepreneurship and its comparison on an international level. A literature analysis was carried out and empirical analysis was performed. The results obtained 
contribute significantly to the existing literature and the implications of the article could be useful for national governments, local authorities, and policymakers in promoting social entrepreneurship initiatives in a different context.

\section{Literature Review}

The analysis of theoretical and empirical studies allows us to conclude that there are a variety of approaches to the social entrepreneurship topic. Thake and Zadek [49], for example, define social entrepreneurship as the desire of entrepreneurs to achieve justice in society and ensure that all people have a decent quality of life. In this case, social entrepreneurship aims to find financially sustainable solutions that help to achieve this purpose. Carraher and Welsh [50] define social entrepreneurship as a process that involves the innovative use and combination of resources to pursue opportunities that trigger social change and address social needs. Peredo and McLean [20] define social entrepreneurship as the identification of a situation that has marginalized or excluded a group of individuals who lack the resources or skills required for an adequate quality of life, and the identification of a way to solve this problem by starting a business. The figure of the social and environmental entrepreneur emerges, who not only aims to create wealth and employment but also responds to social demands that are usually ignored by institutions [51]. Mair and Martí [4] deal with social entrepreneurs and two closely related areas: social entrepreneurship and social enterprises. Based on definitions from various sources, social entrepreneurs are defined as the change agents in social entrepreneurship systems, and social enterprises are defined as private organizations dedicated to solving social problems. In general, most definitions refer to social entrepreneurship as the process of identifying, evaluating, and exploring opportunities to create social value that may occur within or beyond the non-profit, private, for-profit, and public sectors $[4,16,19,52]$. Since a single accepted definition is not possible, social entrepreneurship has recently been understood as an internally complex concept [13], a multidimensional phenomenon [12], or a multidimensional model [21,26,53].

As proposed by Choi and Majumdar [13], social entrepreneurship comprises several sub-concepts that represent the basic characteristics of social entrepreneurship and are identified as (1) social value creation, (2) the social entrepreneur, (3) the social entrepreneurship organization, (4) market orientation, and (5) social innovation. Similarly, Bacq and Janssen [12] divide them into the following subcategories: social entrepreneurs, social entrepreneurship organizations, and the process of social entrepreneurship. Nicholls and Cho [26] propose sociality, innovation, and market orientation as three key dimensions of the concept. With particular reference to non-profit organizations, Weerawardena and Sullivan Mort [21] developed a multidimensional model of social entrepreneurship that includes innovation, proactivity, and risk management. These three key dimensions are constrained by environmental dynamics and the desire to fulfil the social mission and maintain the sustainability of the organization. The above definitions distinguish the two defining characteristics of social enterprises: the undertaking of some form of commercial activity for the purpose of generating income and the simultaneous pursuit of social objectives $[4,20,54,55]$. Thus, social enterprises differ from for-profit organizations (which seek to maximize profit for personal gain) in that they place social change above private wealth creation $[56,57]$. Social enterprises are therefore associated with pro-social motives of wealth creation, cooperation, and community development [58].

A supportive national culture would lead to a social legitimacy that would value and socially recognize entrepreneurial careers, thus creating a favorable institutional environment. A culture that shares more pro-entrepreneurial values and thought patterns would lead to more people showing psychological characteristics and attitudes that are compatible with entrepreneurship $[59,60]$. In this sense, it has been suggested that a high perceived valuation of entrepreneurship in a society leads to more positive attitudes and intentions of individuals $[60,61]$. Although there have been several studies that have examined the effects between entrepreneurship and culture (e.g., [62-66]), little attention has been paid to studying the impact of culture on rates of social entrepreneurship. Several recent GEM-based studies have opened up this interesting research area. Using the GEM data, Stephan and 
Uhlaner [67] conducted a cross-national study involving 40 countries and identified two overarching dimensions of cultural-social supporting culture and performance-oriented culture. They noted that entrepreneurship, in general, is more influenced by a socially supportive culture. Using the same GEM-based data, Liñán et al. [61] showed how the individual perception of the dominant culture affects a person's entrepreneurial intention. Jaén and Liñán [68] went a step further and found evidence of the influence of cultural values on the entrepreneurial attitudes and intentions of individuals. Therefore, the specific cultural values that are a priority in each country will have an impact on the type and level of entrepreneurial activity [69]. In this respect, the differences in entrepreneurship between EU countries [70] should be attributed at least in part to cultural differences.

The culture of the north-western and south-eastern countries of Europe emphasizes intellectual autonomy, equality, and harmony more than any other world cultural region. However, the South-east European cultures are higher than the Northwest European ones in terms of embedding and hierarchy. Official policy in Western Europe attempts to protect universal human rights more strongly than policy in Eastern Europe. This is consistent with the much stronger emphasis on cultural equality versus hierarchy in most of Western Europe than in most of Eastern Europe [71]. European companies are likely to reflect these differences. For example, Western European companies generally provide their employees more rights and better benefits, help them more to develop their skills and realize their potential, and invest more in career planning and development for employees from underrepresented groups. These companies, which are characterized by more egalitarian values, are actually more likely to accept and promote diversity in the workplace, considering the needs of the surrounding community and working in ways that benefit it.

When north-western and south-eastern European companies come into contact with each other, these effects of cultural value differences can lead to miscommunication or conflicts. In sum, the cultural values that prevail in the society in which the organization is located directly influence its cultural values and therefore the norms and practices it develops.

\subsection{Social Value}

A highly valued aspect of social entrepreneurship is the creation of social value (e.g., $[1,13,20])$ as one of the outcomes of social entrepreneurship. Some authors (e.g., [4]) argue that social entrepreneurship emerged as a result of problems in society and creating social value is, therefore, the only objective of social enterprises, while other authors (e.g., [34]) have argued that besides the social value creation the economic value can also be achieved. The fundamental idea behind social entrepreneurship is that it starts because of the existence of a social problem that the traditional market system cannot solve. The social entrepreneurship activity may or may not be profitable, but it has to be financially sustainable. Social value creation can occur anywhere along a continuum from commercial to social entrepreneurship [19] or from non-profit to for-profit organizations [72]. Thus, regardless of the type of business, social entrepreneurship can be understood as the process by which it is possible to create a shared value, "which involves the creation of economic value in a way that also creates value for society by addressing its needs and challenges" [73] (p. 64). Some authors consider the economic value to be completely separate from social value, while others treat the economic value as a kind of social value; yet many other scientists are somewhere between these poles $[20,74]$. The authors agree that it is difficult to assess what social value actually entails and which activities and projects can be considered socially valuable. According to Dees [75], markets do not do a good job of evaluating social improvements, public goods and damages, and benefits to people who cannot afford the payments. These elements are often essential for social entrepreneurship. Consequently, it is much more difficult to determine whether a social entrepreneur creates sufficient social value to justify the resources used to create that value. The survival or growth of a social enterprise is not a proof of its efficiency or effectiveness in improving social conditions. Hossain et al. [76] propose that the result of social entrepreneurship is twofold. First, it aims to create social value, which can be expressed in terms of the intangible assets such as wealth, happiness, and general well-being. Second, it generates economic 
value, which the social enterprise venture can use as a source of sustainability and also the profitability of the social entrepreneur.

Auerswald [74] notes that the concept of social value is very broad and can include financial, reputational, and ethical aspects, consumer surplus, capacity building, and other positive externalities. The breadth of the concept is also reflected in its use in various areas of literature. On the mainstream side of entrepreneurship, Korsgaard and Anderson [77] suggest that entrepreneurship should be anchored as social value creation. The main argument is that there is a commitment to the social side of things on several levels. On the one hand, entrepreneurs are the product of their social context, and the recognition of opportunities is largely determined by their social conditioning. On the other hand, every profit-oriented company also has a social outcome, such as the personal development of the people involved.

Similar to the broader literature on social entrepreneurship, research on social enterprises seeks to determine what constitutes social value, how it can be measured, and whether there can be harmony between social and commercial goals [78]. According to Mair and Martì [4], the literature on social entrepreneurship is widely held to give social value a higher priority than economic value [79].

Finally, there are several studies based on complexity science [80-82] and systems theory [83] to better understand social entrepreneurship in general and social value creation in particular [79]. Furthermore, they define social value creation as the act of creating what serves the greater good (social cause-attractor) and has a higher priority than economic value. Choi and Majumdar [13] conclude that not only is the creation of social value an integral aspect of social entrepreneurship but that the concept of social value itself is a complex and ambiguous one and is, therefore, one of the factors contributing to the internally complex nature of social entrepreneurship.

The social value contributes to the improvement of social well-being and activities related to social inclusion of marginalized groups [84]. Consequently, we state the following research question:

Does there exist differences in the social impact of social enterprises between north-western and south-eastern European countries?

On the basis of the research question we state the first proposition:

Proposition 1: There exist differences in the social impact of social enterprises between north-western and south-eastern European countries.

\subsection{Innovation of Social Enterprises}

Social entrepreneurship is beneficial to society because it is a form of social innovation [85]. According to Thompson and Doherty [86] and Dees [87], social enterprises and social entrepreneurs create innovative initiatives and solutions to unresolved social problems by putting social value creation at the heart of their mission. Social entrepreneurs are described as new engines for reform [87]. In order to fulfil a social mission, it is important that the innovative approach (e.g., [20,88]) is understood as the implementation of new (incremental) ideas, activities, and services [89] inspired by the goal of creating social change. Significantly less attention is paid to forms of innovation that can solve social problems and that are not sufficiently considered by the local public system [14].

On the financing side, social entrepreneurs look for innovative ways to ensure that their companies have access to resources as long as they create social value. This willingness to innovate is part of the way entrepreneurs work. It is not just a one-time burst of creativity. It is a continuous process of exploration, learning, and improvement. Of course, innovation brings with its uncertainty and the risk of failure. Entrepreneurs tend to have a high tolerance for ambiguity and learn how to deal with risks for themselves and others. They treat the failure of a project as a learning experience and not as a personal tragedy [75].

The increased interest in social entrepreneurship and social innovation in recent decades (e.g., $[16,75,90-92])$ can be attributed to the perceived weaknesses and failure of the dominant profit-oriented business model. Social innovation, defined as "innovative activities and services 
motivated by the goal of satisfying a social need" [89] (p. 146), takes place in various forms of organization, ranging from profit-oriented companies (e.g., with their activities in the field of corporate social responsibility) to hybrid organizations and social enterprises [93]. Using multiple theoretical case studies, Weerawardena and Sullivan Mort [43] find that innovation-based competitive strategies of social entrepreneurial non-profit organizations contribute significantly to the achievement of social value. Although considerable research has been carried out on business innovation, especially technological innovation, relatively little research remains on social innovation. There is still a lack of research on social innovation with only some studies in this area, so there is a need for further research on this topic $[94,95]$. Consequently, we state the following research question:

Does there exist differences in the innovation of social enterprises between north-western and south-eastern European countries?

Based on the research question, we state the second proposition:

Proposition 2: There exist differences between the north-western and south-eastern European countries in the innovation of social enterprises.

\subsection{The Market Activity of Social Enterprises}

The broad perspective of social entrepreneurship, in which social entrepreneurs are individuals who start or currently manage any type of activity, organization, or initiative that has a specific social, environmental, or community objective, allows for the inclusion of activities that take place outside the market. Many academics and transnational institutions state that social entrepreneurs should be highly active in the market (e.g., [96,97]). As stated in Glaveli and Geormas [98], despite their social and non-profit character and the emphasis on community, trust, and togetherness, social enterprises are forced by national and transnational policies (critically interpreted as the forced marketing of the non-profit sector) to operate as fully entrepreneurial organizations [99]. In fact, social enterprises are expected to integrate business principles into their operations and adopt an entrepreneurial "attitude" in the provision of social goods and/or services in order to compete and thrive in the demanding and sophisticated contemporary marketplace [100-103].

The market orientation of social entrepreneurship is often associated with the idea of increased efficiency and effectiveness through commercial activities [104], financial sustainability, and self-sufficiency [105-107] on the part of the social enterprise [13]. Market orientation can be expressed in the form of commercial activities that generate earned income in order to ensure the sustainability of social entrepreneurial activities and the self-sufficiency of the organization. In another shading of the idea, market orientation may imply the use of commercial activities directly related to the social mission to ensure the most effective and efficient distribution of social services and products [13]. Consequently, we state the following research question:

Does there exist differences in the market activity of social enterprises between north-western and south-eastern European countries?

Based on the research question, we state the following proposition:

Proposition 3: There exist differences in the market activity of social enterprises between north-western and south-eastern European countries.

\section{Methodology}

The empirical analysis is carried out on a sample of individual-level data from the Global Entrepreneurship Monitor (GEM) database (adult population survey). At least 2000 adults in more than 50 countries participate in the GEM study each year. Using the methodology of the GEM study, the data are valid and reliable (e.g., [108]). In 2015, the GEM study included a special topic on social entrepreneurship. The sample $(n=83,626)$ of our study on special topic represents the adult population (18 to 64 years) of 24 European countries for which the data were available. The GEM methodology 
defines the social entrepreneurship activity as any kind of activity, organization, or initiative that has a specific social, environmental, or community objective. This may include the provision of services or training for socially disadvantaged or disabled persons, activities to reduce environmental pollution or food waste, the organization of self-help groups for community action, etc. The social entrepreneur is defined as a person who starts or currently leads an activity, organization or initiative with a specific social, environmental, or community objective.

For the purpose of our study, the European countries were divided into two groups, namely North-west and South-east Europe, following the GEM survey. North-west Europe includes the following 12 countries: Belgium, Estonia, Finland, Germany, Ireland, Latvia, Luxembourg, Netherlands, Norway, Sweden, Switzerland, and the United Kingdom. South-east Europe also includes 12 countries, namely Bulgaria, Croatia, Greece, Hungary, Italy, Macedonia, Poland, Portugal, Romania, Slovak Republic, Slovenia, and Spain. The GEM data collection methodology enabled to examine further specifications of social entrepreneurship activity, including share of social entrepreneurs with an explicit social mission, offers of products or services on the market, offers of an innovative solution, reinvestment of profits and measuring the social impact of their activities.

To test the differences in various aspects of social entrepreneurship between NwECs and SeECs, the $t$-test was used for independent samples. This type of $t$-test is used to compare two groups of participants who are in no way related and independent of each other. For the $t$-test, the required assumptions were met (e.g., independent observations, normal distribution).

The following variables were used in empirical tests [109]:

- Start-up social entrepreneurship activity: share of the adult population involved in an entrepreneurial activity with a specific social, environmental, or community objective and younger than 3.5 months.

- Operational social entrepreneurship activity: share of the adult population involved in an entrepreneurial activity with a specific social, environmental, or community objective and older than 3.5 months.

- Social impact of start-up social entrepreneurship activity: share of start-up social entrepreneurship activity, that puts efforts into measuring the social and environmental impact of its activities.

- Social impact of operational social entrepreneurship activity: share of operational social entrepreneurship activity, that puts efforts into measuring the social and environmental impact of its activities.

- Innovation of start-up social entrepreneurship activity: share of start-up social entrepreneurship activity, that offers products or services that are new to the market or offers a new way of producing a product or service.

- Innovation of operational social entrepreneurship activity: share of operational social entrepreneurship activity, that offers products or services that are new on the market or offers a new way of producing a product or service.

- Market activity of start-up social entrepreneurship activity: share of start-up social entrepreneurship activity, that is producing and selling goods and services on the market.

- Market activity of operational social entrepreneurship activity: share of operational social entrepreneurship activity, that is producing and selling goods and services on the market.

\section{Results}

In this part of the article, the quantitative data were analyzed, presented in tables, and interpreted. The quantitative data subjected to content analysis and the results were presented in diagrams and tables. The main objective was to examine possible differences between North-west and South-east European countries in the selected characteristics of social enterprises in the start-up and operational developmental phases.

Table 1 provides descriptive statistics for the two groups of countries compared, including the mean and standard deviation.

Table 2 shows the results of the $t$-test for all variables. A $t$-test on independent samples was conducted to compare different aspects of social entrepreneurship activity between NwECs and SeECs. 
Table 1. Group statistics.

\begin{tabular}{cccccc}
\hline & $\begin{array}{c}\text { Group of European } \\
\text { Countries }\end{array}$ & $n$ & Mean & $\begin{array}{c}\text { Std. } \\
\text { Deviation }\end{array}$ & $\begin{array}{c}\text { Std. Error } \\
\text { Mean }\end{array}$ \\
\hline $\begin{array}{c}\text { Social impact of start-up social } \\
\text { entrepreneurship activity }\end{array}$ & North-western (NwECs) & 37,304 & 0.008793 & 0.0933571 & 0.0004834 \\
\cline { 2 - 5 } & South-eastern (SeECs) & 46,322 & 0.007254 & 0.0848594 & 0.0003943 \\
\hline $\begin{array}{c}\text { Social impact of operational social } \\
\text { entrepreneurship activity }\end{array}$ & North-western (NwECs) & 37,304 & 0.015307 & 0.1227712 & 0.0006357 \\
\cline { 2 - 5 } & South-eastern (SeECs) & 46,322 & 0.005850 & 0.0762643 & 0.0003543 \\
\hline $\begin{array}{c}\text { Innovation of start-up social } \\
\text { entrepreneurship activity }\end{array}$ & North-western (NwECs) & 37,304 & 0.006058 & 0.0776002 & 0.0004018 \\
\cline { 2 - 5 } & South-eastern (SeECs) & 46,322 & 0.005894 & 0.0765436 & 0.0003556 \\
\hline $\begin{array}{c}\text { Innovation of operational social } \\
\text { entrepreneurship activity }\end{array}$ & North-western (NwECs) & 37,304 & 0.006916 & 0.0828764 & 0.0004291 \\
\cline { 2 - 5 } & South-eastern (SeECs) & 46,322 & 0.004404 & 0.0662167 & 0.0003077 \\
\hline $\begin{array}{c}\text { Market activity of start-up social } \\
\text { entrepreneurship activity }\end{array}$ & North-western (NwECs) & 37,304 & 0.006380 & 0.0796208 & 0.0004122 \\
\cline { 2 - 5 } & South-eastern (SeECs) & 46,322 & 0.006217 & 0.0786055 & 0.0003652 \\
\hline $\begin{array}{c}\text { Market activity of operational } \\
\text { social entrepreneurship activity }\end{array}$ & North-western (NwECs) & 37,304 & 0.008873 & 0.0937793 & 0.0004855 \\
\cline { 2 - 5 } & South-eastern (SeECs) & 46,322 & 0.005354 & 0.0729745 & 0.0003391 \\
\hline
\end{tabular}

First, we tested the differences between north-western and south-eastern European countries with regard to the social impact of social enterprises using an independent-samples $t$-test. The comparison of the social impact of start-up social enterprises indicated that there was a statistically significant difference in the presence of operational social entrepreneurship activity between NwECs $(M=0.008793$, $\mathrm{SD}=0.09)$ and SeECs $(\mathrm{M}=0.007254, \mathrm{SD}=0.08) ; \mathrm{t}(60,209.129)=2.467, p=0.014$ (two-sided). Similarly, the comparison of the social impact of operational social enterprises showed that there was a statistically significant difference in the presence of operational social entrepreneurship activity between the European countries of NwECs $(\mathrm{M}=0.015307, \mathrm{SD}=0.12)$ and SeECs $(\mathrm{M}=0.005850, \mathrm{SD}=0.08)$; $\mathrm{t}(59,464.991)=12.994, p=0.000$ (two-sided). With regard to the results, we can confirm preposition 1 that there are differences in the social impact of social enterprises between north-western and south-eastern European countries.

Second, we tested the differences between north-western and south-eastern European countries for the innovation of social enterprises using an independent-samples $t$-test. The comparison of the innovation of start-up social enterprises indicated that there was no statistically significant difference in the presence of operational social entrepreneurship activity between NwECs $(\mathrm{M}=0.006058, \mathrm{SD}=0.08)$ and SeECs $(\mathrm{M}=0.005894, \mathrm{SD}=0.08) ; \mathrm{t}(83,624)=0.308, p=0.758$ (two-sided). However, the comparison of the innovation of operational social enterprises showed that there was a statistically significant difference in the presence of operational social entrepreneurship activity between NwECs $(\mathrm{M}=0.006916, \mathrm{SD}=0.08)$ and SeECs $(\mathrm{M}=0.004404, \mathrm{SD}=0.07) ; \mathrm{t}(70,509.241)=4.758, p=0.000$ (two-sided). With regard to the results, we can partially confirm preposition 2 that there are differences in the innovation of social enterprises between north-western and south-eastern European countries. The differences between NwECs and SeECs are confirmed by the innovation of operational social enterprises.

Third, we tested the differences between north-western and south-eastern European countries for the market activity of social enterprises using an independent-samples $t$-test. The comparison of the market activity of start-up enterprises indicated that there was no statistically significant difference in the presence of operational social entrepreneurship activity between NwECs $(\mathrm{M}=0.006380, \mathrm{SD}=0.08)$ and SeECs $(M=0.006217, \mathrm{SD}=0.08) ; \mathrm{t}(83,624)=0.296, p=0.767$ (two-sided). However, the comparison of the market activity of operational social enterprises showed that there was a statistically significant difference in the presence of operational social entrepreneurship activity between NwECs ( $M=0.008873$, $\mathrm{SD}=0.09)$ and SeECs $(\mathrm{M}=0.005354, \mathrm{SD}=0.07) ; \mathrm{t}(69,285.971)=5.942, p=0.000$ (two-sided). With regard to the results, we can partially confirm the preposition 3 that there are differences in the market activity of social enterprises between north-western and south-eastern European countries. The differences between NwECs and SeECs are confirmed by the market activity of operational social enterprises. 
Table 2. Results of $t$-test.

\begin{tabular}{|c|c|c|c|c|c|c|c|c|c|}
\hline & \multicolumn{4}{|c|}{ Levene's Test for Equality of Variances } & \multicolumn{5}{|c|}{$t$-Test for Equality of Means } \\
\hline & \multirow[t]{2}{*}{$\mathbf{F}$} & \multirow[t]{2}{*}{ Sig. } & \multirow[t]{2}{*}{$\mathbf{t}$} & \multirow[t]{2}{*}{ df } & \multirow[t]{2}{*}{$\begin{array}{c}\text { Sig. } \\
\text { (Two-Tailed) }\end{array}$} & \multirow{2}{*}{$\begin{array}{c}\text { Mean } \\
\text { Difference }\end{array}$} & \multirow{2}{*}{$\begin{array}{l}\text { Std. Error } \\
\text { Difference }\end{array}$} & \multicolumn{2}{|c|}{$\begin{array}{l}95 \% \text { Confidence Interval } \\
\text { of the Difference }\end{array}$} \\
\hline & & & & & & & & Lower & Upper \\
\hline $\begin{array}{l}\text { Social impact of start-up social } \\
\text { entrepreneurship activity }\end{array}$ & 24.855 & 0.000 & 2.467 & $76,267.508$ & 0.014 & 0.0015390 & 0.0006238 & 0.0003165 & 0.0027616 \\
\hline $\begin{array}{c}\text { Social impact of operational } \\
\text { social entrepreneurship activity }\end{array}$ & 748.182 & 0.000 & 12.994 & $59,464.991$ & 0.000 & 0.0094563 & 0.0007277 & 0.0080299 & 0.0108827 \\
\hline $\begin{array}{l}\text { Innovation of start-up social } \\
\text { entrepreneurship activity }\end{array}$ & 0.378 & 0.538 & 0.308 & 83,624 & 0.758 & 0.0001648 & 0.0005358 & -0.0008853 & 0.0012149 \\
\hline $\begin{array}{c}\text { Innovation of operational social } \\
\text { entrepreneurship activity }\end{array}$ & 95.025 & 0.000 & 4.758 & $70,509.241$ & 0.000 & 0.0025122 & 0.0005280 & 0.0014773 & 0.0035471 \\
\hline $\begin{array}{l}\text { Market activity of start-up social } \\
\text { entrepreneurship activity }\end{array}$ & 0.350 & 0.554 & 0.296 & 83,624 & 0.767 & 0.0001627 & 0.0005500 & -0.0009153 & 0.0012406 \\
\hline $\begin{array}{l}\text { Market activity of operational } \\
\text { social entrepreneurship activity }\end{array}$ & 149.091 & 0.000 & 5.942 & $69,285.971$ & 0.000 & 0.0035192 & 0.0005922 & 0.0023585 & 0.0046800 \\
\hline
\end{tabular}




\section{Discussion and Conclusions}

The interest of practitioners, policymakers, and academics in social entrepreneurship has grown exponentially over the last decade. The science of social entrepreneurship is characterized by a substantial debate on the definitional, theoretical, and methodological challenges posed by the fact that social entrepreneurship comes from different disciplines and fields (e.g., entrepreneurship, sociology, economics, anthropology, ethics) [21]. Saebi, Foss, and Linder [110], therefore, offer a multilevel framework that shows how research efforts in the field of social entrepreneurship can be linked and what insights about social entrepreneurship on one analytical level imply for the other levels. In terms of the policy level, several economies have designed and implemented policy programs to promote social entrepreneurship. The United Nations and the European Union have also established programs to support social entrepreneurship.

The ecosystems supporting social entrepreneurship and social enterprises can be based on different dimensions. Andersen [111] argues that four dimensions-practice, policy, education, and research-are important elements to stimulate and consolidate. It should be emphasized that the four-dimensional model forms a dynamic, coherent, and interacting system that can both hinder and reinforce development and consolidation [53].

Despite the increase in research, studies on social entrepreneurship are still characterized by the presence of theory and case studies, but only to a limited extent by comparative cross-national empirical research. Understanding the specific contextual characteristics that foster the emergence of social enterprises is an important step forward. In particular, the question of which cultural characteristics favor the development of social entrepreneurship initiatives that can contribute to solving social problems.

Looking at the social impact of social enterprises, the results show that there is a larger proportion of social enterprises measuring their social impact in north-western European countries than in south-eastern countries. As social value versus economic value should be the main objective of social enterprises, it is essential to measure it. However, as already proposed by several previous studies (e.g., [4].), it is difficult to obtain and measure. The reasons for the relatively low level of social impact measurement could, therefore, stem from the internal environment of social enterprises (e.g., lack of resources, if they are very small enterprises, lack of knowledge) or the external environment (e.g., legislation or funding that requires social impact measurement to maintain social enterprise status). An additional comparison of social enterprises in the start-up and operational phase shows that in north-western countries the measurement of social enterprises in the operational phase is increasing compared to the start-up phase. However, in south-eastern countries, more social enterprises measure social impact in the start-up phase than in the operational phase. These issues represent gaps that could be addressed in further research.

Some authors (e.g., [4,28]) claim that social entrepreneurship itself is innovation [85]. As there were no statistically significant differences between north-western and south-eastern countries in terms of innovation in start-up social enterprises, we can conclude that all social enterprises, regardless of cultural context, are aware of the importance of innovation in the creation of social enterprises. However, having already operated as a social enterprise, there are innovations perceived higher in north-western countries than in south-eastern countries. It is interesting to note that in the north-western countries, innovation is higher in the operational social enterprises than in start-up companies. However, in south-eastern countries, it is vice versa, which means that innovation is perceived less by the operational social enterprises than by start-up companies.

With regard to the market activities of social enterprises, there are significant differences between north-western and south-eastern countries in the operational phase. Since market activity contributes to the income of social enterprises and ensures the sustainability of their activities in the long term [97], it appears to be more important in further developmental phases after the start-up phase. It can also be observed in north-western countries, where market activity is increasing in the operational phase. However, it is declining in south-eastern countries. It can happen because companies are based on 
supporting financial resources and measures and therefore have no need to carry out market activities to generate additional income.

However, our research has several limitations which lead to recommendations for further research. First, it is narrowed in the geographical point of view on analyzing social enterprises in European countries. To provide a wider insight into their characteristics, the study should be broadened to other geographical regions. Second, the analysis is based on the existing survey with limited measurement scale and design. New scales could be developed merely for social enterprises with a wider measurement of their characteristics. Third, our analysis is limited only to social enterprises. Their comparison with for-profit enterprises would provide better insight into distinctive features between those two types of enterprises. Additionally, a further limitation is connected also with the methods applied and it could be recommended that more sophisticated analyses are conducted with more variables considered that affect social entrepreneurship.

To sum up, our research reveals several differences between social enterprises operating in different cultural contexts. At the same time, however, we have also opened up some gaps that could be addressed in future research. Among implications is that the social entrepreneurship differs in certain cultures and that policies should take these differences into account. Implications from the theoretical point of view are that social entrepreneurship has its own distinctive features which differ from other types of entrepreneurial activity. Consequently, this type of entrepreneurship should be further explored not only from theoretical but also from the empirical point of view. The implication for policy on this issue on the EU level is to allow the Member States to regulate social entrepreneurship at the national level according to the cultural context in which it appears. The study indicates the importance of culture, which must be considered when developing public policies for social enterprises. Among the managerial implications is that when developing social enterprise, particular features have to be taken into account from the external (e.g., cultural context, legislation, the framework for social entrepreneurship on the national level) as well as from the internal business environment (e.g., enterprise's culture, employees' skills).

Author Contributions: Conceptualization, B.B.H and K.C.; Writing-Original Draft Preparation, B.B.H. and K.C.; Writing-Review and Editing, B.B.H. and K.C. All authors have read and agreed to the published version of the manuscript.

Funding: This research received no external funding.

Conflicts of Interest: The authors declare no conflict of interest.

\section{References}

1. Dees, J.G. Enterprising non-profits. Harv. Bus. Rev. 1998, 76, 54-67.

2. Thompson, J.L.; Alvy, G.; Lees, A. Social entrepreneurship: A new look at the people and the potential. Manag. Decis. 2000, 38, 328-338. [CrossRef]

3. Sullivan Mort, G.; Weerawardena, J.; Carnegie, K. Social entrepreneurship: Towards conceptualization. Int. J. Nonprofit Volunt. Sect. Mark. 2003, 8, 76-88. [CrossRef]

4. Mair, J.; Martí, I. Social entrepreneurship research: A source of explanation, prediction, and delight. J. World Bus. 2006, 41, 36-44. [CrossRef]

5. Miller, T.L.; Grimes, M.G.; Mcmullen, J.S.; Vogus, T.I. Venturing for others with heart and head: How compassion encourages social entrepreneurship. Acad. Manag. Rev. 2012, 37, 616-640. [CrossRef]

6. Acs, Z.J.; Boardman, M.C.; McNeely, C.L. The social value of productive entrepreneurship. Small Bus. Econ. 2013, 40, 785-796. [CrossRef]

7. Phillips, W.; Lee, H.; Ghobadian, A.; O'Regan, N.; James, P. Social innovation and social entrepreneurship: A systematic review. Group Organ. Manag. 2015, 40, 428-461. [CrossRef]

8. Zahra, S.A.; Wright, M. Understanding the social role of entrepreneurship. J. Manag. Stud. 2016, 53, 610-629. [CrossRef]

9. Dwivedi, A.; Weerawardena, J. Conceptualizing and operationalizing the social entrepreneurship construct. J. Bus. Res. 2018, 86, 32-40. [CrossRef] 
10. Haugh, H.; Fergus, L.; Bob, D. Social entrepreneurship: Entrepreneurship and social value creation. In The SAGE Handbook of Small Business and Entrepreneurship; Backburn, R., De Clercq, D., Heinonen, J., Eds.; SAGE: Thousand Oaks, CA, USA, 2018; pp. 125-142.

11. Short, J.C.; Moss, T.W.; Lumpkin, G.T. Research in social entrepreneurship: Past contributions and future opportunities. Strateg. Entrep. J. 2009, 3, 161-194. [CrossRef]

12. Bacq, S.; Janssen, F. The multiple faces of social entrepreneurship: A review of definitional issues based on geographical and thematic criteria. Entrep. Reg. Dev. 2011, 23, 373-403. [CrossRef]

13. Choi, N.; Majumdar, S. Social entrepreneurship as an essentially contested concept: Opening a new avenue for systematic future research. J. Bus. Ventur. 2014, 29, 363-376. [CrossRef]

14. Bonfanti, A.; Battisti, E.; Pasqualino, L. Social entrepreneurship and corporate architecture: Evidence from Italy. Manag. Decis. 2016, 54, 390-417. [CrossRef]

15. Baron, D.P. Corporate social responsibility and social entrepreneurship. J. Econ. Manag. Strategy 2007, 16, 683-717. [CrossRef]

16. Nicholls, A. Social Entrepreneurship: New Models of Sustainable Social Change; Oxford University Press: Oxford, UK, 2008.

17. Mair, J.; Martí, I. Social Entrepreneurship: What are We Talking about? A Framework for Future Research; Working paper No. 546; IESE Business School, University of Navarra: Barcelona, Spain, 2004.

18. Roberts, D.; Woods, C. Changing the world on a shoestring: The concept of social entrepreneurship. Univ. Auckl. Bus. Rev. 2005, 7, 45-51.

19. Austin, J.; Stevenson, H.; Wei-Skillern, J. Social and commercial entrepreneurship: Same, different or both? Entrep. Theory Pract. 2006, 30, 1-22. [CrossRef]

20. Peredo, A.M.; McLean, M. Social entrepreneurship: A critical review of the concept. J. World Bus. 2006, 41, 56-65. [CrossRef]

21. Weerawardena, J.; Sullivan Mort, G. Investigating social entrepreneurship: A multidimensional model. J. World Bus. 2006, 41, 21-35. [CrossRef]

22. Zahra, S.; Gedajlovic, E.; Neubaum, D.; Schulman, J. A typology of social entrepreneurs: Motives, search processes and ethical challenges. J. Bus. Ventur. 2009, 24, 519-532. [CrossRef]

23. Thompson, J.L. The world of the social entrepreneur. Int. J. Public Sect. Manag. 2002, 15, 412-431. [CrossRef]

24. Martín, R.L.; Osberg, S. Social entrepreneurship: The case for definition. Stanf. Soc. Innov. Rev. 2007, 5, $29-39$.

25. Oncer, A.C.; Yildiz, M.L. Creating sustainable value for society: Social entrepreneurship. Bus. Rev. 2010, 14, 222-228.

26. Nicholls, A.; Cho, H.A. Social entrepreneurship: The structuration of a field. In Social Entrepreneurship: New Models of Sustainable Change; Nicholls, A., Ed.; Oxford University Press: Oxford, UK, 2008; pp. 99-118.

27. Certo, S.T.; Miller, T. Social entrepreneurship: Key issues and concept. Bus. Horiz. 2008, 51, 267-271. [CrossRef]

28. Dees, J.G.; Anderson, B.B. For-profit social ventures. Int. J. Entrep. Educ. 2003, 2, 1-26.

29. Cochran, P.L. The evolution of corporate social responsibility. Bus. Horiz. 2007, 50, 449-454. [CrossRef]

30. Kusa, R. Measuring Entrepreneurial Orientation in the Social Context. Entrep. Bus. Econ. Rev. 2016, 4, 117-129. [CrossRef]

31. Verreynne, M.L.; Miles, M.P.; Harris, C. A short note on entrepreneurship as method: A social enterprise perspective. Int. Entrep. Manag. J. 2013, 9, 113-128. [CrossRef]

32. Bansal, S.; Garg, I.; Sharma, G.D. Social entrepreneurship as a path for social change and driver of sustainable development: A systematic review and research agenda. Sustainability 2019, 11, 1091. [CrossRef]

33. Ribeiro-Soriano, D.; Roig Dobon, S. Linking globalization of entrepreneurship in small organizations. Small Bus. Econ. 2009, 32, 233-239. [CrossRef]

34. Dacin, P.A.; Dacin, M.T.; Matear, M. Social entrepreneurship: Why we don't need a new theory and how we move forward from here. Acad. Manag. Perspect. 2010, 24, 58-72.

35. Hill, T.L.; Kothari, T.H.; Shea, M. Patterns of meaning in the social entrepreneurship literature: A research platform. J. Soc. Entrep. 2010, 1, 5-31. [CrossRef]

36. Estrin, S.; Mickiewicz, T.; Stephan, U. Human capital in social and commercial entrepreneurship. J. Bus. Ventur. 2016, 31, 449-467. [CrossRef]

37. Pathak, S.; Muralidharan, E. Informal institutions and their comparative influences on social and commercial entrepreneurship: The role of in-group collectivism and interpersonal trust. J. Small Bus. Manag. 2016, 54, 168-188. [CrossRef] 
38. Hechavarría, D.M.; Terjesen, S.A.; Ingram, A.E.; Renko, M.; Justo, R.; Elam, A. Taking care of business: The impact of culture and gender on entrepreneurs' blended value creation goals. Small Bus. Econ. 2017, 48, 225-257. [CrossRef]

39. Corner, T.; Ho, M. How opportunities develop in social entrepreneurship. Entrep. Theory Pract. 2010, 34, 635-659. [CrossRef]

40. Perrini, F.; Vurro, C.; Costanzo, L.A. A process-based view of social entrepreneurship: From opportunity identification to scaling-up social change in the case of San Patrignano. J. Entrep. Reg. Dev. Int. J. 2010, 22, 515-534. [CrossRef]

41. Lehner, O.M.; Kansikas, J. Opportunity recognition in social entrepreneurship: A thematic meta analysis. J. Entrep. 2012, 21, 25-58. [CrossRef]

42. Chowdhury, I.; Santos, F. Scaling Social Innovations: The Case of Gram Vikas. In Scaling Social Impact. Social Entrepreneurship; Bloom, P.N., Skloot, E., Eds.; Palgrave Macmillan: New York, NY, USA, 2010.

43. Weerawardena, J.; Sullivan Mort, G.S. Competitive strategy in socially entrepreneurial nonprofit organizations: Innovation and differentiation. J. Public Policy Mark. 2012, 31, 91-101. [CrossRef]

44. Santos, F.M. A Positive theory of social entrepreneurship. J. Bus. Ethics 2012, 111, 335-351. [CrossRef]

45. Sundaramurthy, C.; Musteen, M.; Randel, E.A. Social value creation: A qualitative study of Indian social Entrepreneurs. J. Dev. Entrep. 2013, 18, 1-20. [CrossRef]

46. De Clercq, D.; Lim, D.S.K.; Oh, C.H. Individual-level resources and new business activity: The contingent role of institutional context. Entrep. Theory Pract. 2013, 37, 303-330. [CrossRef]

47. Liu, Y.; Almor, T. How culture influences the way entrepreneurs deal with uncertainty in inter-organizational relationships: The case of returnee versus local entrepreneurs in China. Int. Bus. Rev. 2016, 25, 4-14. [CrossRef]

48. Muralidharan, E.; Pathak, S. Informal institutions and international entrepreneurship. Int. Bus. Rev. 2017, 26, 288-302. [CrossRef]

49. Thake, S.; Zadek, S. Practical People, Noble Causes: How to Support Community-Based Social Entrepreneurs; New Economics Foundation: London, UK, 1997.

50. Carraher, S.M.; Welsh, D.H.B. Global Entrepreneurship, 2nd ed.; Kendal Hunt Publishing: Dubuque, IA, USA, 2015.

51. Dacin, T.; Dacin, P.A.; Tracey, P. Social entrepreneurship: A critique and future directions. Organ. Sci. 2011, 22, 1203-1213. [CrossRef]

52. Letts, C.W.; Brown, L.D.; Alvord, S.H. Social Entrepreneurship: Leadership that Facilitates Societal Transformation-An Exploratory Study; Working Paper; Center for Public Leadership, Harvard Kennedy School: Cambridge, MA, USA, 2003.

53. Andersen, L.L.; Gawell, M.; Spears, R. (Eds.) Social Entrepreneurship and Social Enterprise. Nordic Perspectives; Routledge: London, UK, 2016.

54. Laville, J.L.; Nyssens, M. The Social Enterprise. Towards a Theoretical Socio-economic Approach. In The Emergence of Social Enterprise; Borzaga, C., Defourny, J., Eds.; Routledge: London, UK; New York, NY, USA, 2001; pp. 312-332.

55. Peattie, K.; Morley, A. Eight paradoxes of the social enterprise research agenda. Soc. Enterp. J. 2008, 4, 91-107. [CrossRef]

56. Dart, R. The legitimacy of social enterprise. Non-Profit Manag. Leadersh. 2004, 14, 411-424. [CrossRef]

57. Murphy, P.J.; Coombes, S.M. A model of social entrepreneurial discovery. J. Bus. Ethics 2009, 87, 325-336. [CrossRef]

58. Lumpkin, G.T.; Moss, T.W.; Gras, D.M.; Kato, S.; Amezcua, A.S. Entrepreneurial processes in social contexts: How are they different, if at all? Small Bus. Econ. 2013, 40, 761-783. [CrossRef]

59. Krueger, N.F. The Cognitive Psychology of Entrepreneurship. In Handbook of Entrepreneurship Research: An Interdisciplinary Survey and Introduction; Acs, Z.L., Audretsch, D.B., Eds.; Kluwer: London, UK, 2003; pp. 105-140.

60. Fernández, J.; Liñán, F.; Santos, F.J. Cognitive aspects of potential entrepreneurs in Southern and Northern Europe: An analysis using GEM-data. Rev. Econ. Mund. 2009, 23, 151-178.

61. Liñán, F.; Santos, F.J.; Fernández, J. The influence of perceptions on potential entrepreneurs. Int. Entrep. Manag. J. 2011, 7, 373-390. [CrossRef] 
62. Uhlaner, L.; Thurik, R. Postmaterialism influencing total entrepreneurial activity across nations. J. Evol. Econ. 2007, 17, 161-185. [CrossRef]

63. Hechavarria, D.M.; Reynolds, P.D. Cultural norms \& business start-ups: The impact of national values on opportunity and necessity entrepreneurs. Int. Entrep. Manag. J. 2009, 5, 417-437.

64. Reynolds, P.D. Entrepreneurship in developing economies: The bottom billions and business creation. Found. Trends Entrep. 2012, 8, 141-277. [CrossRef]

65. Autio, E.; Pathak, S.; Wennberg, K. Consequences of cultural practices for entrepreneurial behaviors. J. Int. Bus. Stud. 2013, 44, 334-362. [CrossRef]

66. Morales, C.E.; Holtschlag, C. Post materialist values and entrepreneurship: A multilevel approach. Int. J. Entrep. Behav. Res. 2013, 19, 266-282. [CrossRef]

67. Stephan, U.; Uhlaner, L.M. Performance-based vs socially supportive culture: A cross-national study of descriptive norms and entrepreneurship. J. Int. Bus. Stud. 2010, 41, 1347-1364. [CrossRef]

68. Jaén, I.; Liñán, F. Work values in a changing economic environment: The role of entrepreneurial capital. Int. J. Manpow. 2013, 34. [CrossRef]

69. Ma, J.; Todorovic, Z.W. Understanding the role of entrepreneurial quality and national culture on the economic development. Int. J. Entrep. Small Bus. 2012, 16, 299-313. [CrossRef]

70. Kelley, D.J.; Singer, S.; Herrington, M. GEM 2011 Global Report; Babson College: Babson Park, MA, USA; Universidad del Desarrollo: Santiago, Chile; University Tun Abdul Razak: Kuala Lumpur, Malaysia; Global Entrepreneurship Research Association (GERA): London, UK, 2012.

71. Bardi, A.; Sagiv, L. The European Union and Israel: Comparison of cultures and implications. In Europe and Israel; Boehnke, K., Ed.; Deutscher Universitätsverlag: Wiesbaden, Germany, 2003; pp. 13-36.

72. Brooks, A. Social Entrepreneurship: A Modern Approach to Social Value Creation; Pearson: London, UK, 2008.

73. Porter, M.; Kramer, M.R. The big idea: Creating shared value. Harv. Bus. Rev. 2011, 89, 62-77.

74. Auerswald, P. Creating social value. Stanf. Soc. Innov. Rev. 2009, 7, 51-55.

75. Dees, J.G. The Meaning of Social Entrepreneurship; Working Paper; Stanford University: Stanford, CA, USA, 1998.

76. Hossain, S.; Saleh, M.A.; Drennan, J. A critical appraisal of the social entrepreneurship paradigm in an international setting: A proposed conceptual framework. Int. Entrep. Manag. J. 2017, 13, 347-368. [CrossRef]

77. Korsgaard, S.; Anderson, A.R. Enacting entrepreneurship as social value creation. Int. Small Bus. J. 2011, 29, 135-151. [CrossRef]

78. Bull, M. Balance': The development of a social enterprise business performance analysis tool. Soc. Enterp. J. 2007, 3, 49-66. [CrossRef]

79. Sinkovics, N.; Sinkovics, R.R.; Hoque, S.F.; Czaban, L. A reconceptualisation of social value creation as social constraint alleviation. Crit. Perspect. Int. Bus. 2015, 11, 340-364. [CrossRef]

80. Goldstein, J.; Hazy, J.; Silberstang, J. A complexity science model of social innovation in social enterprise. J. Soc. Entrep. 2010, 1, 101-125. [CrossRef]

81. Goldstein, J.; Hazy, J.K.; Trexler, J. Guest editorial: From theory to practice. Emerg. Complex. Org. 2011, 13, 7-10.

82. Swanson, L.A.; Zhang, D.D. Complexity theory and the social entrepreneurship zone. Emerg. Complex. Organ. 2011, 13, 39-56.

83. Dietz, A.S.; Porter, C. Making sense of social value creation: Three organizational case studies. Emerg. Complex. Organ. 2012, 14, 23-43.

84. Głodowska, A.; Szarucki, M. Measuring Social Entreprenership and Social Convergence in Central and Eastern Europe. In Social Supermarkets as Entrepreneruial Ventures in Socially Responsible Economy; Knežević, B., Ed.; University of Zagreb: Zagreb, Croatia, 2018; pp. 23-37.

85. Cernikovaite, M.E.; Lauzikas, M. The model of social innovations in the emerging market of Lithuania. Intelekt. Ekon. 2011, 5, 388-400.

86. Thompson, J.; Doherty, B. The diverse world of social enterprise: A collection of social enterprise stories. Int. J. Soc. Econ. 2006, 33, 361-375. [CrossRef]

87. Dees, J.G. Taking social entrepreneurship seriously. Society 2007, 44, 24. [CrossRef]

88. Luke, B.; Chu, V. Social enterprise versus social entrepreneurship: An examination of the 'why' and 'how' in pursuing social change. Int. Small Bus. J. 2013, 31, 764-784. [CrossRef] 
89. Mulgan, G. The process of social innovation, technology, governance, globalization. MIT Press 2006, 1, 145-162.

90. Christensen, C.; Baumann, H.; Ruggles, R.; Sadtler, T. Disruptive innovation for social change. Harv. Bus. Rev. 2006, 84, 94-191.

91. Leadbeater, C. The Rise of the Social Entrepreneur; Demos: London, UK, 1997.

92. Shaw, E.; Carter, S. Social entrepreneurship: Theoretical antecedents and empirical analysis of entrepreneurial processes and outcomes. J. Small Bus. Enterp. Dev. 2007, 14, 418-434. [CrossRef]

93. Dees, J.G.; Anderson, B.B. Framing a theory of social entrepreneurship: Building on two schools of practice and thought. In Research on Social Entrepreneurship: Understanding and Contributing to an Emerging Field; Occasional Paper Series 1 (3); Mosher-Williams, R., Ed.; ARNOVA: Indianapolis, IN, USA, 2006; pp. $39-66$.

94. Mulgan, G.; Tucker, S.; Ali, R.; Sanders, B. Social Innovation: What it is, Why it Matters, How it Can be Accelerated; Skoll Centre for Social Entrepreneurship: Oxford, UK, 2007.

95. Murray, R.; Caulier-Grice, J.; Mulgan, G. Social Venturing; The Social Innovator Series; Nesta: London, UK, 2009.

96. Defourny, J.; Nyssens, M. Conceptions of social enterprise and social entrepreneurship in Europe and the United States: Convergences and divergences. J. Soc. Entrep. 2010, 1, 32-53. [CrossRef]

97. Defourny, J.; Nyssens, S. Fundamentals for an international typology of social enterprise models. Volunt. Int. J. Volunt. Nonprofit Organ. 2017, 28, 2469-2497. [CrossRef]

98. Glaveli, N.; Geormas, K. Doing well and doing good. Int. J. Entrep. Behav. Res. 2018, 24, 147-170. [CrossRef]

99. Bull, M. Challenging tensions: Critical, theoretical and empirical perspectives on social enterprise. Int. J. Entrep. Behav. Res. 2008, 14, 268-275. [CrossRef]

100. Kickul, J.; Walters, J. Recognizing new opportunities and innovations: The role of strategic orientation and proactivity in internet firms. Int. J. Entrep. Behav. Res. 2002, 8, 292-308. [CrossRef]

101. Borzaga, C.; Bodini, R.; Carini, C.; Depedri, S.; Galera, G.; Salvatori, G. Europe in Transition: The Role of Social Cooperatives and Social Enterprises, Euricse Working Papers No. 69. 2014. Available online: www.euricse.eu/wp-content/uploads/2015/03/1405514708_n2553.pdf (accessed on 16 January 2020).

102. Krlev, G. Strategies in social entrepreneurship: Depicting entrepreneurial elements and business principles in SEOs from Germany and Bangladesh. J. Entrep. Perspect. 2012, 1, 61-96.

103. Piboonrungroj, P. Understanding social enterprise: Theory and practices. Int. J. Entrep. Behav. Res. 2012, 18, 743-745. [CrossRef]

104. Nicholls, A. The legitimacy of social entrepreneurship: Reflexive isomorphism in a pre-paradigmatic field. Entrep. Theory Pract. 2010, 34, 611-633. [CrossRef]

105. Boschee, J.; McClurg, J. Toward a Better Understanding of Social Entrepreneurship: Some Important Distinctions, Working Paper. 2003. Available online: http://toolbelt.se-alliance.org/resources/180 (accessed on 21 January 2020).

106. Harding, R. Social enterprise-The new economic engine? Bus. Strategy Rev. 2004, 15, 39-43. [CrossRef]

107. Haugh, H. A research agenda for social entrepreneurship. Soc. Enterp. J. 2005, 1, 1-12. [CrossRef]

108. Reynolds, P.; Bosma, N.; Autio, E.; Hunt, S.; De Bono, N.; Servais, I.; Lopez-Garcia, P.; Chin, N. Global entrepreneurship monitor: Data collection design and implementation 1998-2003. Small Bus. Econ. 2005, 24, 205-231. [CrossRef]

109. Bosma, N.; Schott, T.; Terjesen, S.; Kew, P. Social Entrepreneurship, Special Topic Report; Global Entrepreneurship Research Association, London Business School: London, UK, 2016.

110. Saebi, T.; Foss, N.J.; Linder, S. Social Entrepreneurship Research: Past Achievements and Future Promises. J. Manag. 2018, 45, 70-95. [CrossRef]

111. Andersen, L.L. Concepts in Social Entrepreneurship and Social Innovation: Nordic Council Workgroup on Social Entrepreneurship and Social Innovation; Keynote Speech, 3 February; Nordic Council Meeting, Malmö University: Malmö, Sweden, 2014.

(C) 2020 by the authors. Licensee MDPI, Basel, Switzerland. This article is an open access article distributed under the terms and conditions of the Creative Commons Attribution (CC BY) license (http://creativecommons.org/licenses/by/4.0/). 